\title{
Assessing Supplier-Customer Relationship Management Practice and Business Performance
}

\author{
Chijioke Nwachukwu1, Vu Minh Hieu2* \\ \{cesogwa@yahoo.com ${ }^{1}$, hieu.vm@vlu.edu.vn² \\ ${ }^{1}$ Business School, Horizons University Paris, France \\ ${ }^{1}$ Department of Financial Technologies, South Ural State University Chelyabinsk, Russia \\ 2*(Corresponding author) Faculty of Business Administration, Van Lang University, Vietnam
}

\begin{abstract}
The To remain competitive firms must develop and implement strategies to attract and retain key suppliers and customers. Drawing on transaction cost economics (TCE) and social exchange theory (SET), this study shed light on the link between supplier relationship management (SRM) practices, customer relationship management (CRM) practices and business performance. The paper uses surveys conducted on microfinance banks operating in Nigeria. This study used correlation and regression to analyse the direct influence of SRM practices and CRM practices on business performance. Data from 307 respondents affirm that supplier relationship management practices and customer relationship management practices increase business performance. Furthermore, supplier relationship management practices and customer relationship management are significantly correlated with financial health, market and sales performance and operational performance. We conclude that implementing strong collaboration with suppliers and customers can foster superior business performance.
\end{abstract}

Keywords: SRM, CRM, microfinance banks, business performance, financial health.

\section{Introduction}

In today's highly competitive environment, securing a competitive edge is crucial for business expansion and survival. To manage business complexities and improve performance, organisations need to execute strategies and policies that focus on service delivery. In this context, customer relationship management (Eisingerich and Bell, 2006) and supplier relationship management are such strategies. Strategic management of supplier-customer relationships has emerged as a key consideration for producing superior market outcomes in scholarly and practitioner literature. As a result, businesses must evaluate their investment decisions around the supply chain to optimise supplier-customer processes (Hananiah, Miller, Richards and Cavusgil, 2003; Silva, Bradley and Sousa, 2012). More so, inadequate resources are exposing firms to production and distribution risks which are impacting negatively on their business performance. Thus, optimising all available resources has become a challenge for firms (Modi and Mabert, 2007). Nonetheless, this challenge also presents opportunities for building supplier-customer relationships. Indeed, these relationships can enable firms to effectively use their resources in managing successful transactions as well as encourage joint performance and long-term exchange (Kremic et al., 2006).

By value co-creation, supplier-customer partnerships have the power to promote mutual profitability (Lusch and Vargo, 2006; Enz and Lambert, 2012). Managers must do this by 
establishing long-term strategic relationships with suppliers and customers by proactive supplier-customer relationship management.Supplier relationship management (SRM) focuses on the preparation, execution, development, and tracking of a company's existing and future supplier relationships (Akamp and Müller, 2013). Arguably, creating a relationship with the best suppliers can facilitate the timely delivery of products and services and improve product quality. Links between operations and suppliers have been shown to improve firm efficiency (Swink et al., 2007; Singh and Power, 2009; Flynn et al., 2010) and the potential to co-create value (Enz and Lambert, 2012). According to research, supplier partnership management has become a challenge (Muhia and Afande, 2015), and company maturity is limited (Klemettinen, 2018). Several scholars (e.g. Gatobu and Moronge, 2018; Njagi and Shalle, 2016; Kähkönen and Lintukangas, 2012) have called for further research on supplier relationship management in different contexts. Customer relationship management (CRM), on the other hand, is concerned with the direct relationship between consumers and advertisers, as well as the retention of new customers and the development of long-term partnerships with them (Sanzo and Vasquez, 2011). The opportunity for customer relationship management has arisen as a result of the changing market climate (Soltani and Navimipour, 2016). Customer relationship management (CRM) aims to boost customer loyalty by providing goods and services that match or surpass their expectations.CRM has been shown to have an effect on corporate success (Day and Van den Bulte, 2002; Reinartz, Krafft, and Hoyer, 2004), business performance (Palmatier, et al, 2006), and consumer performance (Day and Van den Bulte, 2002). (e.g. Mithas, Krishnan and Fornell, 2005). Nevertheless, there is limited studies on CRM process and firm performance in under-developed economies (Ngambi and Ndifor, 2015).

Intense competition has forced microfinance banks in Nigeria to seek a long-term profitable relationship with suppliers and customers to deliver superior business performance. Nwachukwu et al. (2017) opined that managers of microfinance banks need to execute effective strategies and policies to improve performance and create value for their stakeholders. Considering the dynamic nature of the Nigerian microfinance banking sector, and the paucity of research on the subject (supplier-customer relationship management practices), this paper intends to investigate the effects of SRM-CRM practices on the performance of microfinance banks. The aim of this paper is to investigate the connection between SRM-CRM activities and business results (financial health, market and sales performance and operational performance). This paper makes the following important contributions: First, the paper adds to the existing literature on supplier-customer relationship management practices in microfinance banks in the emerging market contexts. As a result, this paper adds to the discourse about how to build and maintain client relationships by offering methodological observations into the effect of mixed supplier and customer relationship management approaches on business success.By shedding light on how SRM practices and CRM practice affect the performance of microfinance banks, this study enhances the understanding of what drives the performance of microfinance banks. Furthermore, relating SRM-CRM practices to operational performance extends the SRM-CRM literature (Arawati, 2011; Hamid and Hamid, 2014). Empirical studies on the impact of SRM practices, CRM practices on operational performance is scanty, in establishing a positive connection between SRM practices, CRM practices and operational performance, this study adds to empirical findings on the relationship between SRM practices, CRM practices in operational performance contexts (e.g. Shobayo, 2017). The below is the outline of the document.Theoretical foundation, an overview of the literature on SRM practice-business performance link, CRM practice-business performance link, and the research hypotheses. 
Next, is the methodology used and the presentation of the research results. Finally, the theoretical and practical implications of the results are discussed.

\section{Theoretical foundation}

The costs of creating, maintaining, and controlling a firm's commercial operation in a market are known as transaction costs. Relationship interaction should be based on economic considerations which organise and constrain a firm's behaviour and promote cooperation, minimising partners' incentives for opportunism, disputes, and transaction costs, according to transaction cost economics (TCE) (e.g. Luo et al., 2015).TCE can be used to explain how various types of investments within firms can create long-term capabilities and foster performance (Grover and Malhotra, 2003). Indeed, the ability of a firm to collaborate with a strategic partner to provide them with services and maintain the relationship is a source of competitive advantage. TCE can enrich our understanding of whether it is beneficial for firms to maintain robust supplier relationship management practices. Besides, TCE can be used to evaluate the quality and richness of the relationships as well as the value of creating partnership between different firms. Social exchange theory (SET) is considered as an appropriate theoretical lens to explain customer-supplier relationships because it offers social ways to manage a relationship and enhance cooperation (Liu et al., 2009; Hawkins et al., 2008; Li et al., 2010). SET is widely used to explain customer-supplier relationships (e.g. Granovetter, 2005; Luo, 2002). SET suggest that actions of individuals are motivated by what they get from others (Blau, 1964). The key drivers of relationship sharing are confidence and loyalty, and SET focuses on reciprocating benefits between relationship partners (Blau, 1964; Palmatier, 2008). TCE and SET have been used by academics to clarify how governance considerations affect inter-firm results (e.g. Ferguson et al., 2005).As a result of research on inter-firm relationship governance, the impact of relationships on business success has been identified (Poppo and Zenger, 2002; Terpend, Tyler, Krause and Handfield, 2008; Dyer and Chu, 2011; Liu, Luo and Liu, 2009; Luo, Liu, Yang, Maksimov and Hou, 2015; Liu et al., 2017). Arguably, firms can use successful cooperation/collaboration (supplier-customer relationship management practice) to reduce transaction costs and conflicts and improve the performance of relationship exchange. In the context of this study, optimising SRM-CRM practices can enable firms to reduce cost and enhance business performance.

\section{Link between supplier relationship management and performance}

Organisations are striving to create long-term strategic partnerships with innovative suppliers and cooperate with them in providing solutions and responding to changing business needs. Strategic supplier relationship management creates value to organisations through creativity among suppliers (Tarafdar and Qrunfleh, 2013). Supplier relationship management enables firms to optimize their supply base to achieve competitive advantage (Schuh et al., 2014). Indeed, strategic partnerships with suppliers can enable firms to develop new and efficient products and enhance their performance. Arguably, firms can reduce costs, create new products and value by optimising long-term collaboration with key suppliers. Researchers have reported that suppliers play a major role in driving firms' operational performance (e.g., Wagner and Krause, 2009; Modi and Mabert, 2007). Tangus et al. (2015) found that supplier relationship management activities were linked to manufacturing company success in Kenya. Supplier partnership management affects procurement efficiency in fast-moving consumer goods manufacturing companies, according to Gatobu and Moronge (2018). According to the 
report, strong supplier coordination frees up managerial time, lowers job costs, and increases organisational stability.Al-Abdallah et al. (2014) investigated the impact of supplier relationship management activities on competitive success in Japan, Korea, the United States, and Italy.They observed that firms cannot rely only on their internal resources and capabilities but must strategically manage the relationship with their suppliers to achieve competitive performance. Krause, Handfield, and Tyler (2007) found that firms' loyalty to long-term partnerships with main suppliers, common priorities and principles with suppliers, and participation in supplier growth programmes have a major impact on purchasing company competitive success in the US automotive and electronics industries. In light of the above, the following theories were suggested in this study:

H1. Supplier relationship management practice significantly influences business performance.

H1a. Supplier relationship management practice is positively correlated to financial health.

H1b. Supplier relationship management practice is positively associated with market and sales performance.

H1c.Supplier relationship management practice is positively correlated with operational performance.

\section{Link between customer relationship management and performance}

Customer Relationship Management (CRM) is built on the ideals of Relationship Marketing (RM) (Rahimi and Kozak, 2017). Customer relationship management focuses on creating and improving the portfolio of customer relationships (Zablah et al., 2004). Customer relationship management aims at creating and maintaining individual relationships with key customers using the right information and communication technologies (Nguyen, Sherif and Newby, 2007; Bose 2002). Customer relationship management emphasizes developing and maintaining relationships with customers in every position to leverage relationship value (Richards and Jones, 2008). CRM focuses on building and maintaining long-term relationships with consumers (Josiassen, Assaf, and Cvelbar, 2014) and relies on data gathered prior to making decisions (Khosravifar, Bentahar, Gomrokchi, and Alam, 2012). According to Giannakis-Bompolis and Boutsouki (2014) CRM is "a comprehensive strategy and process of acquiring, retaining, and partnering with selective customers to create superior value for the company and the customer". Arguably, CRM is a managerial activity that focuses on optimising relationships with customers to maximize relationship value. Lambert (2010) opines that the customer relationship management process is successful when there is a positive impact on the profitability of specific customer or segment of customers over time. Customer relationship management practices can enhance product and service quality through feedback from customers. Ramani and Kumar (2008) assert that customer relationship management is effective and efficient in building innovation capabilities which help firms achieve competitive advantage. Reinartz (2004) submitted that CRM activities lead to superior business performance. Anuforo et al. (2015) investigated the interaction between customer relationship management and commercial bank success in two cities in Nigeria's Abia State. Customer relationship management (CRM) has a significant impact on customer satisfaction, sales value, and market share, according to the researchers. To achieve their business goals, commercial banks in Nigeria should sustain close cooperation with their customers, according to the study.Simonet, Kamdem, and Nguefack (2012) reported that customer relationship management is connected to the commercial performance of Microfinance institutions in Cameroon. Contrarily, Ngambi and Ndifor (2015) found that CRM does not have a positive effect on the performance of Microfinance Institutions in Cameroon. Customer relationship 
management strategies, we conclude, would have a substantial and constructive effect on company success.

H2. Customer relationship management practice significantly influences business performance.

H2a. Customer relationship management practice is positively correlated to financial health.

$\mathrm{H} 2 \mathrm{~b}$. Customer relationship management practice is positively associated with market and sales performance.

$\mathrm{H} 2 \mathrm{c}$. Customer relationship management practice is positively correlated with operational performance.

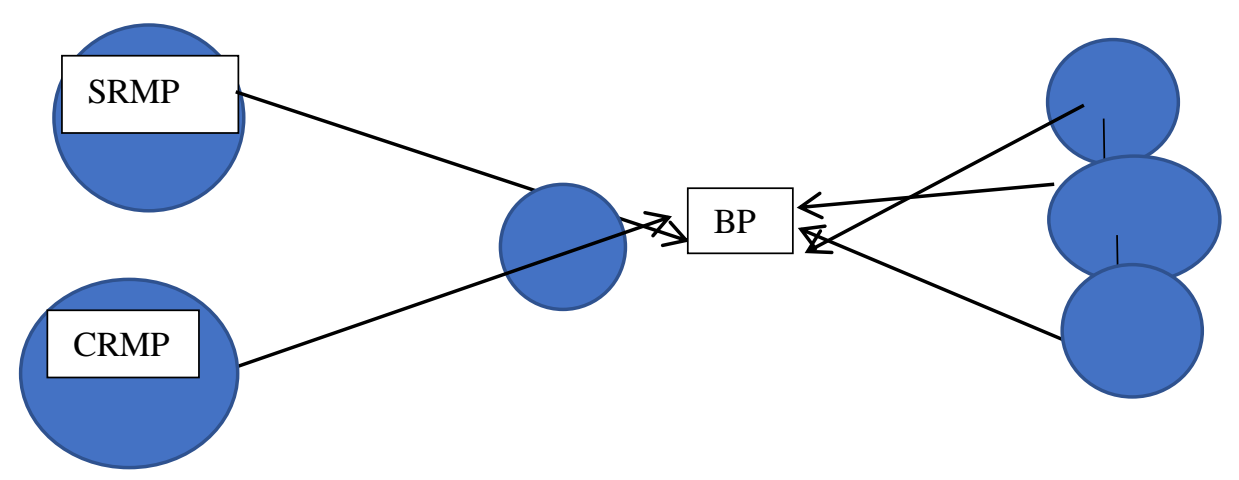

Figure 1. Conceptual model showing the relationship between the research variables

Source: Authors elaboration

Note: $\mathrm{SRMP}=$ supplier relationship management practices, $\mathrm{CRMP}=$ customer relationship management practices, $\mathrm{BP}=$ business performance, $\mathrm{FH}=$ financial health, $\mathrm{MSP}=$ market and sales performance, $\mathrm{OP}=$ operational performance.

\section{Methodology}

\subsection{Research questions}

The aim of this research is to provide answers to the following questions;

- Does supplier relationship management practice influence business performance dimensions (financial health, market and sales performance operational performance)?

- Is customer relationship management practice related to business performance dimensions (financial health, market and sales performance operational performance)?

\subsection{Sample data and demographics}

The study used data obtained from microfinance banks operating in Nigeria. The survey took place between the months of July and September 2018 covering MFBs located in 3 geopolitical zones in the country). Microfinance banks are well-represented in these geographical areas. The existing state of microfinance in Nigeria, as well as potential 
challenges, can be mitigated by developing novel skills (Nwachukwu et al., 2018). Nigeria has one of Africa's biggest markets, with crude oil revenues being a main source of income.Authors sent online survey to 450 respondents who were randomly selected. We sent the survey connect to the respondents' e-mail addresses to ensure that only specific individuals participated in the online survey.Completed responses from managers saddled with the responsibility of managing suppliers and customers relationships of this MFBs were used in this analysis.In the end, 307 completed responses from these firms were analyzed. The sample size is appropriate and within the recommended sample size (Bryman, 2004). Patel et al., 2015; Parida and rtqvist, 2015) found that a single industry analysis reduces the possible noise that comes from many industry studies. This represents a $68 \%$ response rate which is appropriate analysing the resultant data and for drawing conclusion (Bryman and Bell, 2015).

3.3. Measures and analytical approach

To address the needs of this report, the European Foundation for Quality Management (EFQM, 2013) scale was adapted and updated. Part A of the questionnaire sought information on supplier relationship management practises, customer relationship management practises, and business performance. Part B of the questionnaire sought information on supplier relationship management practises, customer relationship management practises, and business performance. Part B gathered information on the firm's profile. Three questions were used to assess supplier partnership management activities. Three items were used to evaluate customer relationship management practices. Three questions were used to access supplier relationship management practices, which includes: (i) We chose our suppliers based on our strategy and manage our relationship with them accordingly, (ii) Our relationship with our suppliers is based on mutual trust respect, and openness, (iii) Our cooperation with our supplier is based on sustainable benefits. To evaluate customer relationship management practices, three questions were used to collect information from respondents; (i)We handle and improve customer relationships by understanding the needs and expectations of our various customer groups; (ii) we establish and sustain a dialogue with all of our customers based on accountability, honesty, and trust; and (iii) we conduct daily customer surveys with metrics that track consumer satisfaction.Performance is a construct which has many definitions. It is independent from the purpose and is something achieved by an individual or organisation (Dugguh and Ayaga, 2014). Customer-related results of company success have been recorded in the literature (e.g, Kaplan and Norton, 1996). To measure business performance, single questions each was used to assess financial health, market and sales performance and operational performance. As with multiple-item scales, single-item tests have a high statistical validity (Bergkvist and Rossiter, 2007, 2009). A 5-point Likert scale ranging from $1=$ strongly accept to $5=$ strongly disagree was used to evaluate supplier relationship management activities, customer relationship practises, and company results. The subjective measure was used to operationalised business performance because of lack of access to financial data. Cronbach's alpha for customer relationship management practices (0.71), supplier relationship management practices (0.67), business performance (0.76) and the overall scale $(0.80)$ suggests that the questionnaire effectively measures the variables in this study (Zikmund et al., 2013). The KMO and Bartlett's measure of sampling adequacy were both important (KMO: $0.776, P=0.000<0.05$ ), and the sample size was greater than 0.5. (Hair et al., 2010). Experts have checked the measurement scale's face truth, comprehensiveness, and coherency. For data analysis, descriptive and inferential statistics were used. The relationship between SRM practises, CRM practises, and financial stability, business and revenue efficiency, and operating performance was investigated using correlation analysis. The role of supplier relationship management (SRM) and customer relationship management (CRM) activities on 
company success is determined using regression analysis. The data was analysed using the Statistical Kit for Social Sciences (SPSS 25) programme.

\subsection{Handling common method bias}

Managers responsible for managing suppliers-customers collaboration can give reliable information about the subject. Evaluation apprehension was minimized by assuring respondents anonymity (Conway and Lance, 2010; Podsakoff et al., 2003). We used a cover letter to keep it apparent that the independent variable measurements are unrelated to the dependent variable measurements. To ensure comprehensiveness and coherency, a group of six academic and non-academic experts carefully constructed and checked scale pieces. Furthermore, correlations of more than 0.9 between the variables suggest typical process bias (Bagozzi et al., 1991). The structures with the highest correlation (supplier relationship management practise and customer relationship management practise) had a correlation of 0.494 , indicating that there was no traditional process bias problem (see table 2 ).

\section{Empirical Findings}

In terms of employee numbers, $46(15 \%)$ of MFBs have between 1 and 10 workers, 206 $(67 \%)$ have between 11 and 20 employees, 49 (16\%) have between 21 and 30 employees, and $6(2 \%)$ have between 31 and 40 employees. Just $3(1 \%)$ respondents said their companies had been in the market for 11 years or more, while $15(5 \%)$ said they had been in the market for 0 to 5 years, $289(94 \%)$ said they had been in the market for 6 to 10 years, and $15(5 \%)$ said they had been in the market for 11 years or more.

Table 1. Descriptive Statistics on supplier-customer relationship management practice/ business performance

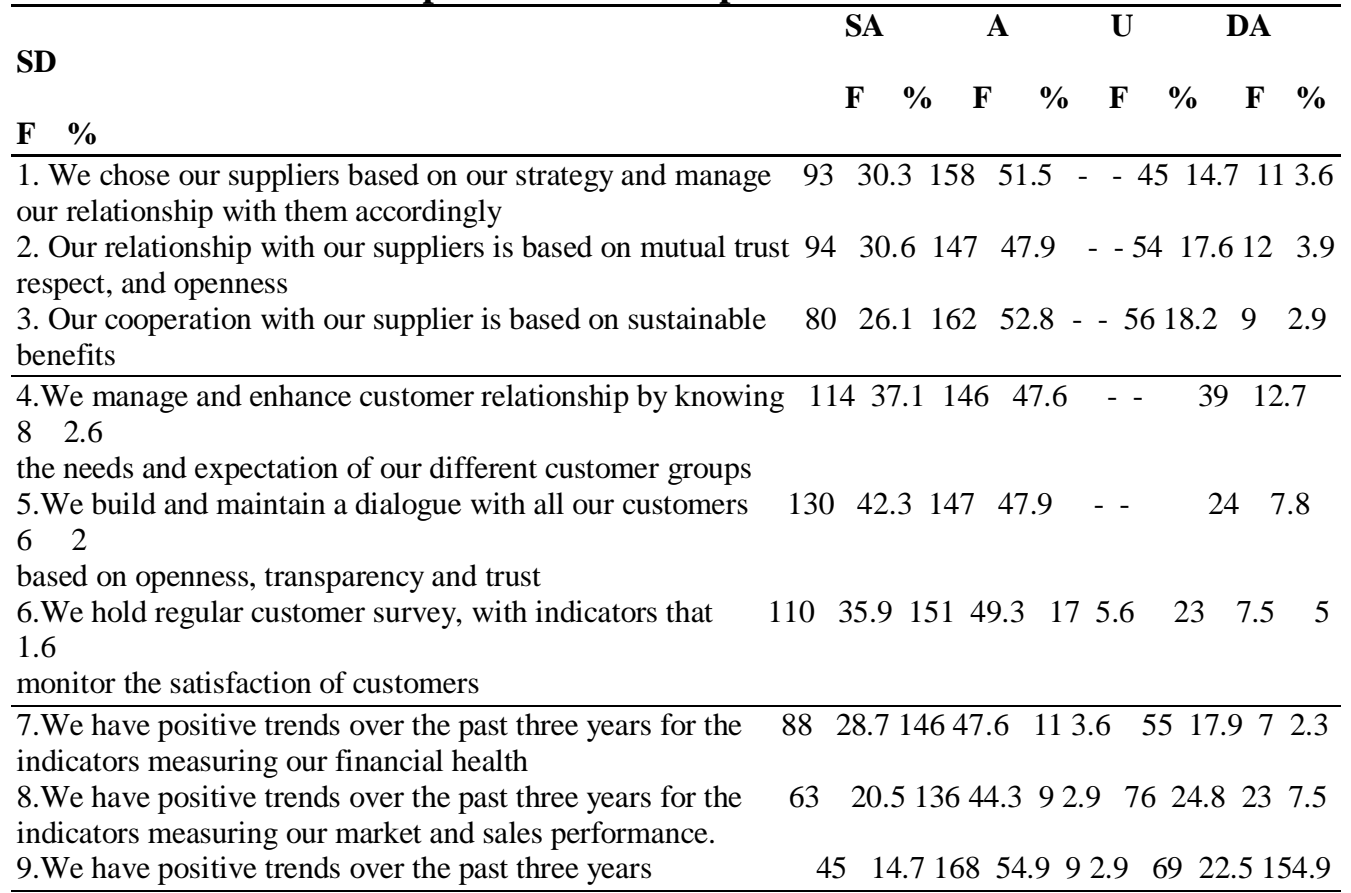


for the indicators measuring our operational performance

\section{Source: Own, 2019}

Table 1 indicates the respondents' responses to the following comments about supplier partnership management practice: We choose our vendors in accordance with our plan, and we maintain our relationships with them accordingly $(30.3 \%)$ strongly agree, $(51.5 \%)$ agree, $(14.7$ $\%)$ disagreed and $(3.6 \%)$ strongly disagreed, our relationship with our suppliers is based on mutual trust,respect, and openness (30.6\%) strongly agree, (47.9\%) agree, (17.6\%) disagreed and $(3.9 \%)$ strongly disagreed, our cooperation with our supplier is based on sustainable benefits $(26.1 \%)$ strongly agree, $(52.8 \%)$ agree, (18.2\%) disagreed and $(2.9 \%)$ strongly disagreed. With respect to customer relationship management practice: Knowing the interests and expectations of our various client classes helps us handle and improve customer relationships $(37.1 \%)$ strongly agree, (47.6\%) agree, (12.7\%) disagreed and (2.6\%) strongly disagreed, we establish and handle a dialogue with all our customers based on openness, transparency and trust (42.3\%) strongly agree, $(47.9 \%)$ agree, $(7.8 \%)$ disagreed and $(2 \%)$ strongly disagreed, We hold regular customer survey, with indicators that monitor the satisfaction of customers (35.9\%) strongly agree, (49.3\%) agree, (5.6\%) undecided, (7.5\%) disagreed and $(1.6 \%)$ strongly disagreed. In terms of business performance: We have positive trends over the past three years for theindicators measuring our financial health $(28.7 \%)$ strongly agree, (47.6\%) agree, (3.6\%) undecided, (17.9\%) disagreed and (2.3\%) strongly disagreed, we have positive trends over the past three years for theindicators measuring our market and sales performance $(20.5 \%)$ strongly agree, $(44.3 \%)$ agree, $(2.9 \%)$ undecided, $(24.8 \%)$ disagreed and $(7.5 \%)$ strongly disagreed, we have positive trends over the past three years for the indicators measuring our operational performance $(14.7 \%)$ strongly agree, $(54.9$ $\%)$ agree, $(2.9 \%)$ undecided, $(22.5 \%)$ disagreed and (4.9\%) strongly disagreed.

\section{Table 2. Correlation results}

\begin{tabular}{lcc}
\hline \multicolumn{1}{c}{ SRM } & CRM & \\
\hline Financial health & $0.418^{* *}$ & $0.425^{* *}$ \\
Pearson Correlation & 0.000 & 0.000 \\
Sig. (2-tailed). & $0.271^{* *}$ & $0.233^{* *}$ \\
Market/sales performance & 0.000 & \\
Pearson Correlation & & \\
Sig. (2-tailed).0.000 & $0.280^{* *}$ & $0.214^{* *}$ \\
Operational performance & 0.000 & \\
Pearson Correlation & 1 & $0.494^{* *}$ \\
Sig. (2-tailed).0.000 & & 0.000 \\
Supplier relationship management & & 1 \\
Pearson Correlation & $0.494^{* *}$ & \\
Sig. (2-tailed). & 0.000 & \\
Customer relationship management & Pearson Correlation &
\end{tabular}

$\mathrm{N}=307$, **. Correlation is significant at the 0.01 level (2-tailed).

Table 3. Regression results 


$\begin{array}{llcc}\beta & & 0.287 & 0.205 \\ \mathrm{t} & & 4.797 & 3.423 \\ \mathrm{P} \text {-value } & 0.000 & 0.000 & 0.001 \\ \mathrm{VIF} & & 1.323 & 1.323 \\ \mathrm{R} & 0.427 & & \\ \mathrm{R}^{2} & 0.183 & & \\ \mathrm{~F} & 33.712 & & \\ \text { Durbin Watson } & 2.060 & & \end{array}$

$\mathrm{N}=307$, **. Correlation is significant at the 0.01 level (2-tailed). *. Correlation is significant at the 0.05

level (2-tailed).

Source: Authors, 2019

Presented in Table 2 is the results testing hypotheses $1 \mathrm{a}, 1 \mathrm{~b}, 1 \mathrm{c}, 2 \mathrm{a}, 2 \mathrm{~b}$ and $2 \mathrm{c}$. The result $\left(\mathrm{R}=0.418^{* * *}, \mathrm{P}=0.000<0.05\right)$ support $\mathrm{H1a}$ that supplier relationship management practices is positively correlated to financial health. $\left(\mathrm{R}=0.271^{* * *}, \mathrm{P}=0.000<0.05\right)$ suggest that supplier relationship management practice is positively associated with market and sales performance $(\boldsymbol{H} 1 \boldsymbol{b})$. The $\left(\mathrm{R}=0.280^{* *}, \mathrm{P}=0.000<0.05\right)$ support H1c , supplier relationship management practice is positively correlated with operational performance. The R-value for customer relationship management practice on financial health $(\boldsymbol{H} 2 \boldsymbol{a})$, is positive $0.425^{* *}$ with a p-value of 0.000 , suggesting that the relationship is statistically significant. Furthermore, the R-value for customer relationship management practices on market and sales performance has a positive value of $0.233^{* * *}$ and a p-value of $0.000(\boldsymbol{H} 2 \boldsymbol{b})$, indicating that customer relationship management practice is positively associated with market and sales performance. Similarly, the R-value for customer relationship management practices on operational performance $(\boldsymbol{H} 2 \boldsymbol{c})$ is $0.214^{* *}$ with a p-value of 0.000 , which shows that customer relationship management practice is positively correlated with operational performance. Presented in Table 3 is the results testing hypotheses 1 and 2 . The coefficient value $(\beta)$ for supplier relationship management practices on business performance $(\boldsymbol{H 1})$ is $0.287^{* *}$ with a p-value of 0.000 , indicates that supplier relationship management practices influence the performanceof microfinance banks. The coefficient value $(\beta)$ for customer relationship management on business performance $(\boldsymbol{H} 2)$ is $0.205^{* *}$ with a p-value of 0.001 , suggesting that customer relationship management practices influence the performance of microfinance banks. The result $\left(\mathrm{R}^{2}=0.183\right)$ further shows that supplier relationship management practice and customer relationship management practice jointly explain $18.3 \%$ variation in microfinance bank performance.The variance inflation factor 1.323 is less than 5 , indicating that there is no multicollinearity problem (Ringle et al., 2015). These findings show that the method has strong calculation properties. The lack of autocorrelation in the method is shown by the Durbin-Watson test value of 2.060 .

Table 4. Hypotheses test results/ decision

\begin{tabular}{lcc}
\hline Hypotheses & P-value & Remark/decision \\
\hline H1 & 0.000 & Accept \\
H1a & 0.000 & Accept \\
H1b & 0.000 & Accept \\
H1c & 0.000 & Accept \\
H20.001 & & \\
H2a & Accept & \\
\hline
\end{tabular}




\begin{tabular}{lll}
$\mathrm{H} 2 \mathrm{~b}$ & 0.000 & Accept \\
$\mathrm{H} 2 \mathrm{c}$ & 0.000 & Accept \\
\hline
\end{tabular}

Source: Author, 2019

\section{Discussions and conclusions}

\subsection{Key findings and implications}

The objective of this study is to look at the connection between supplier and consumer relationship management in terms of business performance. Survey data from 307 microfinance banks suggest an overall positive influence of SRM-CRM practices on business performance. Given that this relationship has been a source of contention in the marketing/supply chain management literature,(e.g., Muhia and Afande, 2015; Klemettinen, 2018; Gatobu and Moronge, 2018; Njagi and Shalle, 2016), the current findings contribute to theoretical claims and limited observational research on the topic in the context of growing markets. This research relates to the field of transaction cost economics (TCE) (e.g. Luo et al., 2015) and social exchange theory (SET) (e.g. Liu et al., 2009; Hawkins et al., 2008) by establishing that successful cooperation/collaboration (supplier-customer relationship management) have positive effect on business performance. It was insightful to find that SRM practices, CRM practices shows a positive and significant correlation with financial health, market and sales performance and operational performance. This study reveals that SRMCRM practices are important for the performance of microfinance banks. Therefore, SRMCRM practices are key areas that should be considered in future studies in marketing/supply chain management. The findings of the research support previous studies on the importance of supplier relationship management in enhancing performance. For instance, Gatobu and Moronge, (2018) who observed that that supplier relationship management foster procurement performance in fast-moving consumer goods manufacturing firms, Tangus et al., (2015) who reported that supplier relationship management practices impact performance of manufacturing firms in Kenya, Al-Abdallah et al. (2014) who found that supplier relationship management practices foster competitive performance selected manufacturing firms in Japan, Korea, USA, and Italy and Krause, Handfield and Tyler (2007) who observed that supplier relationship management practices are linked to firm competitive performance. This results also support past empirical studies that reported a positive link between customer relationship management and performance (e.g. Simonet et al., 2012; Anuforo et al., 2015; Reinartz, 2004). Indeed, improving the relationship with customers can lead to profitable and sustainable performance. However, this finding deviates from the submission of Ngambi and Ndifor (2015) who concluded that CRM does not have a positive effect on performance. The paper also contributes to empirical research on microfinance banks, especially in Nigeria. Microfinance banks provide services that support the growth and development of small businesses as well as the Nigeria economy (Nwachukwu, 2018). However, MFBs are faced with challenges that emanate from intense competition, sophistication in technology and market uncertainties. Consequently, developing, executing and maintaining robust suppliercustomer relationship management practices can enable them to adapt to these challenges and improve their performance.

\subsection{Managerial Implications}

The results have several implications for managers and executives of microfinance banks. The important role of suppliers and customers need special attention from managers and 
executives in delivering superior performance. In this context, microfinance banks in Nigeria can take strategic decisions on how to develop a robust relationship/collaboration with their suppliers and customers to achieve better performance. The future of firms depends on creating and managing supplier-customer relationships that will meet current and future business needs. Implementing strong collaboration can improve their ability to attract and retain suppliers and customers. Firms should implement strong SRM practices as this directly influences performance (financial health, market and sales performance, operational performance). To achieve this, they should choose suppliers based on their strategy and manage the relationship with them accordingly. It is important to build and manage the relationship with suppliers' base on mutual trust, respect, and openness. Trust, respect and openness can foster a strong relationship with key suppliers, enhance value creation and sustainable benefits. The supplier network contributes positively to the performance of firms by making available quality products and services in a short time and at the lowest cost. Thus, firms that aspire to be market leaders must adopt a strategic approach to managing the relationships with suppliers. Strategically managing relationships with suppliers can lead to product innovations that would make firms to achieve better performance. Indeed, firms with robust supplier relationship management practices outwit their peers in term of performance. To remain in business, MFBs need to create tactics to retain their customers, minimise the cost of attracting new ones and reposition themselves towards the customer-focused business philosophy. One way of doing this is for executives and managers to implement strong customer relationship management practices. Creating and implementing effective and efficient practices that focus on the customer relationship can lead to microfinance bank's success They need to manage and improve customer relationship by anticipating the needs and expectation of different customer groups. To cope with rapidly changing customer expectations, firms must develop collaborative relationships with customers. This relationship with customers should be based on openness, transparency and trust. Furthermore, it is important to hold regular customer survey and monitor the level of customer satisfaction. In so doing, the firms will be able to attract and retain their customers. Thus, reducing customer attrition and improve business performance. Finally, failure to implement SRM-CRM practices may lead to loss of important customers and suppliers which can be costly, both directly and indirectly. Consequently, firms may fail to achieve their strategic objectives.

\subsection{Limitations and outlook}

This study has some shortcomings. First, subjective data on business performance (financial health, market and sales performance, operational performance) was used. Future studies can use objective data where available and additional indicators of business performance using multiple scales. The use of larger sample sizes to examine the subject in various contexts (industries and countries) might provide new insights. Future studies can consider the use of longitudinal data sets to examine potential changes over time. Future researchers should continue to search for moderating and mediating variables as this might enhance our understanding of the SRM-CRM practice - performance relationship, particularly firm-specific factors (e.g size, age). Despite these drawbacks, this section reviews the literature by highlighting the important impact of SRM and CRM methods on successful organization in a developing industry.

\section{References}


[1] Akamp, M. and Müller, M. (2013).Supplier management in developing countries. Sustain. Manag. Corp. Boundaries 56, pp. 54-62.

[2] Al-Abdallah, G. M., Abdallah, A. B and Hamdan, K. B. (2014).The Impact of Supplier Relationship Management on Competitive Performance of Manufacturing Firms. International Journal of Business and Management, 9(2), pp. 192-202.

[3] Anuforo, R., Ogungbangbe, B. M. and Edeoga, G. (2015). A Study of the Impact of Customer Relationship Management on Bank Growth in Nigeria, Journal of Social Economics, 2(4), pp. 177-187.

[4] Arawati, A. (2011). Supply chain management, supply chain flexibility and business performance. Journal of Global Strategic Management, 5(1), 134-145.

[5] Bagozzi, R. P., Yi, Y. and Phillips, L. W. (1991).Assessing construct validity in organizational research. Adm. Sci. Q. 36, 421-458.

[6] Bergkvist, L. and Rossiter, J. R. (2007). The predictive validity of multiple-item versus singleitem measures of the same constructs. Journal of Marketing Research, 44(2), 175-184.

[7] Bergkvist, L. and Rossiter, J. R. (2009). Tailor-made single-item measures of doubly concrete constructs. International Journal of Advertising, 28(4), 607-621.

[8] Blau, P. M. (1964). Exchange and Power in Social Life, New York: Wiley.

[9] Bose, R. (2002). Customer relationship management: Key components for IT success. Industrial Management \& Data Systems, 102(2) pp. 89-97.

[10] Bryman, A. (2004). Social Research Methods, 2nd ed., Oxford: Oxford University Press

[11] Conway, J. M. and Lance, C. E. (2010). What reviewers should expect from authors regarding common method bias in organizational research. Journal of Business and Psychology, 25(3), pp. 325-334.

[12] Day, G. S. and Van den Bulte, C. (2002). Superiority in customer relationship management: consequences for competitive advantage and performance. working paper, Wharton School, University of Pennsylvania.

[13] Dugguh, S. I. and Ayaga, D. (2014). Job satisfaction theories: Traceability to employee performance in organizations. Journal of Business and Management, 16(5), pp. 11-18.

[14] Dyer, J. H. and Chu, W. (2011).The determinants of trust in supplier-automaker relationships in the US, Japan, and Korea. Journal of International Business Studies, 42(1), pp. 10-27.

[15] EFQM (2013).The EFQM Excellence Model.Retrieved from: www.efqm.org.

[16] Eisingerich, A. B. and Bell, S. J. (2006). Relationship marketing in the financial services industry: the importance of customer education, participation and problem management for customer loyalty. Journal of Financial Services Marketing, 10, pp. 486-97.

[17] Enz, M. G and Lambert, D. M. (2012).Using cross-functional, cross-firm teams to co-create value: The role of financial measures. Industrial Marketing Management, 41(3), pp. 495-507.

[18] Ferguson, R. J., Paulin, M. and Bergeron, J. (2005). Contractual governance, relational governance, and the performance of interfirm service exchanges: the influence of boundaryspanner closeness. Journal of the Academy of Marketing Science, 33(2), pp. 217-234.

[19] Flynn, B. B., Huo, B. and Zhao, X. (2010). The impact of supply chain integration on performance: a contingency and configuration approach. Journal of Operations Management, 28(1), pp. 58-71.

[20] Gatobu, J. G. and Moronge, M. (2018). Influence of supplier relationship management on procurement performance in fast moving consumer goods manufacturing firms in Nairobi City County, Kenya. The Strategic Journal of Business \& Change Management, 5(1), pp. 745- 768.

[21] Giannakis-Bompolis, C and Boutsouki, C. (2014). Customer Relationship Management in the Era of Social Web and Social Customer: An Investigation of Customer Engagement in the Greek Retail Banking Sector. Procedia-Social and Behavioral Sciences, 148, pp. 67-78.

[22] Granovetter, M. (2005).The impact of social structure on economic outcomes. The Journal of economic perspectives, 19(1), pp. 33-50.

[23] Grover, V. and Malhotra, M. K. (2003). Transaction cost framework in operations and supply chain management research: theory and measurement. Journal of Operations Management, 21(4), pp. 457-473. 
[24] Hair, J., Black, W., Babin, B. and Anderson, R. (2010) Multivariate data analysis, 7th ed., Englewood Cliffs: Prentice Hall

[25] Hamid, K. and Hamid, R. A. (2014). Study of performance measurement practices in supply chain management. Proceedings of the 2014 International Conference on Industrial Engineering and Operations Management Bali, Indonesia, January 7 - 9, pp. 273-285.

[26] Hanvanich, S., Miller, S. R., Richards, M. and Cavusgil, S. T. (2003).An event study of the effects of partner and location cultural differences in joint ventures. International Business Review, 12(1), pp. 1-16.

[27] Hawkins, T. G. Wittmann, C. M. and Beyerlein, M. M. (2008). Antecedents and consequences of opportunism in buyer-supplier relations: Research synthesis and new frontiers. Ind. Mark.Manag. 37, pp. 895-909.

[28] Josiassen, A., Assaf, A. G. and Cvelbar, L. K. (2014). CRM and the bottom line: Do all CRM dimensions affect firm performance? International Journal of Hospitality Management, 36, pp. 130-136.

[29] Kähkönen, A. K. and Lintukangas, K. (2012).The underlying potential of supply management in value creation. Journal of Purchasing \& Supply Management,18(2), pp. 68-75.

[30] Kaplan, R. S., \& Norton, D. P. (1996). The balanced scorecard: Translating strategy into action. Harvard Business Press.

[31] Khosravifar, B., Bentahar, J., Gomrokchi, M. and Alam, R. (2012). CRM: An efficient trust and reputation model for agent computing. Knowledge-Based Systems, 30, pp. 1-16.

[32] Klemettinen, J. (2018). Supplier Relationship Management: influence of effective relationship management on competitive advantage. Lappeenranta University of technology published master thesis.

[33] Krause, D., Handfield, R. and Tyler, B. (2007).The relationships between supplier development, commitment, social capital accumulation and performance improvement. Journal of Operations Management, 25(2), pp. 528-545.

[34] Kremic, T., IcmeliTukel, O. and Rom, W. O. (2006).Outsourcing decision support: a survey of benefits, risks, and decision factors.Supply Chain Management: An International Journal, 11(6), pp. 467-482.

[35] Li, Y., Xie, E., Teo, H. and Peng, M. W. (2010).Formal control and social control in domestic and international buyer-supplier relationships.Journal of Operations Management, 28(4), pp. 333-344.

[36] Liu, Y., Luo, Y. and Liu, T. (2009). Governing buyer-supplier relationships through transactional and relational mechanisms: Evidence from China. Journal of Operations Management, 27(4), pp. 294-309.

[37] Liu, Y., Luo, Y., Huang, Y. and Yang, Q. (2017).A diagnostic model of private control and collective control in buyer-supplier relationships.Industrial Marketing Management, 63, pp. 116-128.

[38] Luo, Y. (2002). Contract, cooperation, and performance in international joint ventures.Strategic Management Journal, 23(10), pp. 903-919.

[39] Luo, Y. (2005). Transactional characteristics, institutional environment and joint venture contracts. Journal of International Business Studies, 36(2), pp. 209-230.

[40] Luo, Y., Liu, Y., Yang, Q., Maksimov, V and Hou, J. (2015). Improving performance and reducing cost in buyer-supplier relationships: the role of justice in curtailing opportunism. Journal of Business Research, 68(3), pp. 607-615.

[41] Lusch, R. F. and Vargo, S. L. (2006). The service-dominant logic of marketing, Armonk, NY: M.E. Sharpe.

[42] Mithas, S., Krishnan, M. S. and Fornell, C. (2005). Why do customer relationship management applications affect customer satisfaction? Journal of Marketing, 69(4), pp. 201-209.

[43] Modi, S. B. and Mabert, V. A. (2007). Supplier development: Improving supplier performance through knowledge transfer. Journal of Operations Management, 25(1), pp. 42-64. 
[44] Muhia, D. W. and Afande, F. O. (2015). Adoption of e-procurement strategy and procurement performance in State Corporations in Kenya: A Case of Kenya Revenue Authority. Industrial Engineering Letters, 5(6), pp. 1-24.

[45] Ngambi, M. T. and Ndifor, P. S. (2015). Customer Relationship Management and Firm Performance: revisiting the case Of the Camccul Microfinance Institutions. International Journal of Information Technology and Business Management, 38(1), pp. 12-21.

[46] Nguyen, T. H., Sherif, J. S. and Newby, M. (2007).Strategies for successful CRM implementation. Information Management \& Computer Security, 15(2), pp. 102-115.

[47] Njagi, M. M. and Shalle, N. (2016). Role of supplier relationship management on procurement performance in manufacturing sector in Kenya: A case of East African Breweries. International Academic Journal of Procurement and Supply Chain Management, 2(1), pp. 1-20.

[48] Nwachukwu, C. (2018). The impact of different types of innovations on customer satisfaction in microfinance bank in Nigeria.Published MBA Thesis, Jamk University of Applied Sciences, Jyvaskyla, Finland.

[49] Nwachukwu, C., Chladkova, and Olatunji, F. (2018).Strategy Formulation Process and Innovation Performance Nexus. International Journal for Quality Research, 12(1), pp. 147-164.

[50] Nwachukwu, C., Chladkova, H., Zufan, P. and Olatunji, F. (2017).Visionary Leadership and Its Relationship to Corporate Social Performance. Imperial Journal of Interdisciplinary Research, 3(4), pp. 1302-1311.

[51] Palmatier, R. W. (2008). Interfirm relational drivers of customer value. Journal of Marketing, 72(4), 76-89.

[52] Palmatier, R. W., Dant, R. P., Grewal, D. and Evans, K. R. (2006). Factors influencing the effectiveness of relationship marketing: a meta-analysis. Journal of marketing, 70(4), pp. 136153.

[53] Parida, V. and Örtqvist, D. (2015). Interactive effects of network capability: ICT capability, and financial slack on technology-based small firm innovation performance. Journal of Small Business Management, 53, pp. 278-298.

[54] Patel, P. C., Kohtamäki, M., Parida, V. and Wincent, J. (2015). Entrepreneurial orientation asexperimentation and firm performance: The enabling role of absorptive capacity. Strategic Management Journal, 36(11), pp. 1739-1749.

[55] Podsakoff, P., MacKenzie, S., Lee, J. and Podsakoff, N. (2003). Common method biases in behavioural research: A critical review of the literature and recommended remedies. Journal of Applied Psychology, 88, pp. 879-903.

[56] Poppo, L. and Zenger, T. (2002). Do Formal Contracts and Relational Governance Function as Substitutes or Complements? Strategic Management Journal, 23(8), pp. 707-725.

[57] Rahimi, R. and Kozak, M. (2017). Impact of customer relationship management on customer satisfaction: The case of a Budget Hotel Chain. Journal of Travel \& Tourism Marketing, 34(1), pp. $40-51$.

[58] Reinartz, W. Krafft, M. and Hoyer, W. D. (2004). The customer relationship management process: Its measurement and impact on performance. Journal of marketing research, 41(3), pp. 293-305.

[59] Ringle, C. M., Wende, S. and Becker, J-M. (2015). SmartPLS 3.Bönningstedt: SmartPLS. Retrieved from http://www.smartpls.com

[60] Sanzo, M. J \& Vasquez, R. (2011). The Influence of Customer Relationship Marketing Strategies on Supply Chain Relationships: The Moderating Effects of Environmental Uncertainty and Competitive Rivalry. Journal of Business-to-Business Marketing, 18, pp. 5082.

[61] Schuh, C., Strohmer, M. F., Easton, S., Hales, M. and Triplat, A. (2014) Supplier Relationship Management -How to maximize supplier value. A press. [online] Available at: https://linkspringer-com.ezproxy.cc.lut.fi/content/pdf/10.1007\%2F978-1-4302-6260-2.pdf

[62] Shobayo, P. B. (2017). Supply chain management and operational performance in Nigeria: a panel regression model approach. International Journal of Entrepreneurial Knowledge, 5(2), pp.66-77. 
[63] Silva, S. C., Bradley, F. and Sousa, C. M. P. (2012).Empirical test of the trust performance link in an international alliance's context.International Business Review, 21(2), pp. 293-306.

[64] Simonet, M. A., Kamdem, D. and Nguefack, C. (2012). Impact of the Customer relationship management on the performance of the Institutions of Microfinance in Cameroon: The case of the Camccul network. International Journal of Management \& Information technology, 1(3), pp. 37-53.

[65] Singh, P. and Power, D. (2009). The nature and effectiveness of collaboration between firms, their customers and suppliers: a supply chain perspective. Supply Chain Management: An International Journal, 14(3), pp. 189-200.

[66] Soltani, Z. and Navimipour, N. J. (2016). Customer relationship management mechanisms: A systematic review of the state-of-the-art literature and recommendations for future research. Computers in Human Behavior, 61, pp. 667-688.

[67] Swink, M., Narasimhan, R. and Wang, C. (2007).Managing beyond the factory walls: effects of four types of strategic integration on manufacturing plant performance. Journal of Operations Management, 25(1), pp. 148-64.

[68] Tangus, C., Oyugi, L. A. and Rambo, C. (2015).Effect of supplier relationship management practices on performance of manufacturing firms in Kisumu County, Kenya.International Journal of Economics, Commerce and Management, 3(2), pp. 499-512.

[69] Tarafdar, M. and Qrunfleh, S. (2013). Lean and agile supply chain strategies and supply chain responsiveness: the role of strategic. Supply Chain Management: An International Journal, 18(6), pp. $571-582$.

[70] Terpend, R., Tyler, B. B., Krause, D. R. and Handfield, R. B. (2008). Buyer-supplier relationships: Derived value over two decades. Journal of Supply Chain Management, 44(2), pp. 28-55.

[71] Wagner, S. M. and Krause, D. R. (2009). Supplier development: communication approaches, activities and goals. International Journal of Production Research, 47(12), pp. 3161-3177.

[72] Zablah, A. R., Bellenger, D. N. and Johnston, W. J. (2004). An evaluation of divergent perspectives on customer relationship management: Towards a common understanding of an emerging phenomenon. Industrial Marketing Management, 33(6), pp. 475-489.

[73] Zikmund, W. G., Babin, B. J., Carr, J. C. and Griffin, M. (2013).Business research methods. 9th ed., USA: South-Western, Cengage Learning. 